\title{
Magyarország 2025-ben és kitekintés 2050-re
}

\author{
Hungary in 2025 and forecast to 2050
}

\author{
Szerző: Schmidt Péter ${ }^{a} \bowtie$, Veszprémi Károlynéb \\ a: Egyetemi Oktató Gyermekorvosi Rendelö, Györ b: Petz Aladár Megyei Oktató Kórház Orvosi \\ Könyvtár, Györ
}

Beküldve: 2017.06.02.

doi: $10.24365 /$ ef.v58i2.154

Kulcsszavak: könyvismertetés; fiatalok; jövő társadalma; demográfia

Keywords: book review; youth; future society; demography

Magyarország 2025-ben és kitekintés 2050-re címmel tanulmánykötet jelent meg Nováky Erzsébet professzor asszony tiszteletére.

Az Arisztotelész Kiadó 2016-ban megjelent kötetében 22 írás olvasható 33 szerzőtől, akik a kiemelkedő kutató és oktató pályatársai, tanítványai, barátai és tisztelői. A Tóth Attiláné és S. Gubik Andrea által szerkesztett és összeállított 299 oldal terjedelmú kötetet nyomdatechnikai és komoly tartalmi igényesség jellemzi. A közölt tanulmányok szakértői vizsgálatokra, valamint fiatalok körében végzett empirikus felmérésekre alapozottan vetítik előre Magyarország 2025-ben várható társadalmi, gazdasági, technológiai, környezeti helyzetét, egyúttal előrejelzést adnak a 2050-es évekre.

A kötet tanulmányai szerves folytatása a Magyar Tudományos Akadémia támogatásával 2007-2010 között végzett Magyarország 2025 című kutatásnak.

Nováky Erzsébet a Budapesti Corvinus Egyetem Professor Emeritája. A 70. születésnapjára megjelent kötet a professzor asszony 1970 óta tartó jövőkutatási munkássága és személye előtt tiszteleg.

A jeles jövőkutató fő vizsgálati területe a komplex társadalmi-gazdasági előrejelzés és a Magyarország 2025-ben kutatási témakör. Az előszóban Tóth Attiláné méltatja és beszámol a professzor asszony felfelé ívelő tudományos pályájának főbb állomásairól, az általa betöltött társasági-szervezeti tisztségeiről, munkája elismeréséül kapott kitüntetéseiről és díjairól, valamint és nem utolsó sorban, megnyerő személyiségéről.

A kötet három részre tagolva, három sokat mondó főcím köré csoportosítva tartalmazza a tanulmányokat. $1,2,3,4,5,6$

„Az ember a jövő társadalmában” főcímmel szereplő első részben tizenegy tanulmány olvasható:

Kiss Éva professzor „Területi különbségek a hazai népesség egészségi állapotában és a jövőbeni kilátások" címú tanulmánya a területi különbségekkel, az egészségi állapotban megjelenő eltérések okaival, az egészségbeli állapotot befolyásoló fontosabb tényezők területi sajátosságaival foglalkozik. ${ }^{7}$ Térbeli szempontból is vizsgálja az egészségügyi kilátásokat. 15 térképes ábrával teszi még szemléletesebbé az általa leírtakat.

Schmidt Péter gyermekgyógyász főorvos, profeszszor tanulmánya - „A népesség számának és egészségi állapotának várható alakulása" ${ }^{8}$ - elemzi és egyúttal színes diagramok felhasználásával teszi szemléletessé a fő hazai demográfiai mutatókat. 
Górcső alá kerül a magyar körte alakú korfa, párhuzamba állítva a 2014-es adatokat a 2050-re előrevetített képpel. Ezen túl az elemzésben többek között a magyarországi élve születési, mortalitási és morbiditási adatok is szerepelnek. A szerző az izgalmas „Mi lesz velünk 2050-ben?” - kérdést is felteszi, melyre optimista, realista és egy pesszimista változatban is megadja a választ, majd végső konklúzióként kiemeli az egészségnevelés egyénre és társadalomra kivetített fontosságát az egészség-megőrzés komplex feladataként.

Besenyei Lajos munkája „A munkaerőpiac generációs struktúrájának alakulása a XXI. század első felében" bevezetésként a ma élő generációkat klasszifikálja és jellemzi az informatikai vívmányokhoz történő viszonyulásuk alapján, majd szembesülhetünk a Z generációt, azaz az informatikai és virtuális világba beleszületetteket érintő tanulási és oktatási problémákkal, ellentmondásokkal, dilemmákkal. Besenyei tanulmánya végén a $Z$ generáció és a munkaerőpiac közötti viszonyt, kettejük kölcsönös egymásra hatását elemzi.

Bernschütz Mária, Dörnyei Krisztina és Nováky Erzsébet „A Z-generáció a jövőről - empirikus vizsgálat eredményei" címú tanulmányukban 2015-ös kutatásuk eredményeit elemzik. A közel ezerötszáz válaszadói minta alapján végzett felmérés képet ad arról, hogyan gondolkodnak a 2000 körül született generáció tagjai a jövőről, hogyan látják benne magukat, mit gondolnak a 2025-ös évek Magyarországáról. Színes grafikonok sora teszi könnyebbé az eligazodást a vizsgálat adatai között.

S Gubik Andrea a Miskolci Egyetemi docenseként a magyar egyetemi hallgatók karrierterveit és ezek kihatását vizsgálja vállalkozói hajlandóságukra. („Magyar egyetemi hallgatók karrierterveinek alakulása és kihatásuk a jövőbeli vállalkozói hajlandóságra") Elemezve az adatokat összefoglalásként elmondható, hogy jelenleg a felsőoktatásban tanuló fiatalok elsősorban alkalmazotti létben képzelik el jövőjüket, a vállalkozói lét alig jelent számukra vonzerőt. A szerző tanulmányában kitér arra, hogy mely társadalmi, attitúdbeli és gazdasági változások vezettek el ide, illetve megerősíti annak szükségességét, hogy a vállalkozás múködtetéséhez szükséges tudást iskolai keretek között kell biztosítani a $Z$ és $Y$ generáció tagjainak.
Vass Zoltán a Magyar Diáksport Szövetség szenior szakértője a fiatalok testi-lelki állapotával kapcsolatosan a 2007-től napjainkig jellemző tendenciákat, az ezzel kapcsolatos félelmeit és reményeit, valamint a szükséges teendőket vázolja fel „Mit tehetünk és mit érhetünk el a fiatalok fizikai-lelki állapotának javítása érdekében?" - címú elgondolkodtató munkájában, kiemelve a rendszeres fizikai aktivitás és ezzel összefüggésben az egészségtudatos életvezetés fontosságát.

Hullám István és Kappéter István közös munkája „Az időskorúak, a lelki betegek és a deviánsok helyzete és ellátása 2025-ben és 2050-ben" áttekintést ad arról, hogy 2015-16-ban mit látunk másként egy korábban - 2010-ben - megjelent tanulmányban megfogalmazott várakozásokhoz képest. ${ }^{9}$ Vizsgálatuk többek között kiterjed a demensek, időskorúak, mentális problémákkal küzdők társadalmi elfogadásában történt változásokra, a globalizáció, a napjainkban zajló népvándorlás hatásaira, illetve a pszichiátriai ellátás lehetséges átalakulására.

Szilágyi Gyula szociológus „Félidőben (és még tovább)" címmel a magyarországi társadalom egy-egy csoportjának jövőjét vetíti előre. Írásában foglalkozik a nemzetiségiekkel, romákkal, a zsidósággal, a szexuális mássággal és végül a hajléktalanság kérdésével.

Benedek András professzor az oktatás és tanulás területén jelentkező ellentmondásokkal foglalkozik az „Új tanulási és tanítási módok a XXI. század első felében" címú írásában. Megállapítja, hogy bár az információs és kommunikációs technikai eszközök száma és minősége robbanásszerúen emelkedik, ezt a gyors fejlődést a hazai oktatási rendszer egyelőre még nem tudja követni és átemelni az oktatás tartalmi és módszertani fejlesztésébe.

Koncz Gábor egyetemi magántanár „A népesség kulturáltsági színvonalának változása 2025-ig” címü munkája a bennünket érő kulturális, társadalmi, környezeti és egyéb hatásokat, változásokat veszi számba a rendszerváltástól napjainkig.

Diczig István ügyvéd a hazai bűnügyi előrejelzésről ír, kiemelve a terrorizmust, a korrupciót, a környezetvédelemi vonatkozásokat, megemlítve még a pénzügyi szektorbeli, informatikai bűncselekménye- 
ket, valamint az elégtelen pszichiátriai ellátás kriminalisztikai veszélyeit.

A tanulmánykötet második részének címe: „Globalizáció, nemzetközi erőviszonyok, gazdaság”.

Kiss Endre professzor a jövőre nézve legnagyobb kihívásként a globalizációból, az információtechnika gyors fejlődéséből, a migrációs helyzetből és ezek kölcsönhatásaiból fakadó változásokat jelöli meg „A globalizáció kiváltotta félelmek és remények" címú írásában.

Antalóczy Katalin, Gáspár Tamás, Majoros Pál, Moldicz Csaba, Novák Tamás, Pólyi Csaba és Szanyi Miklós írásának címe magáért beszél: „A nemzetközi erőviszonyokban várható változások". Elemzik a demográfia és migráció, a multinacionális vállalatok, a pénzügyi rendszer, a nemzetközi kereskedelem, a nyersanyag és élelmiszerpiac változásait. Emellett a globális átrendeződés és az ebből fakadó változások az államok mozgásterében, valamint az Európai Unió is vizsgálatuk tárgya. Írásuk megállapításait ábrákkal is szemléltetik.

Bartha Zoltán és Tóth Szita Klára széles spektrumra kiterjedő, magyar viszonyokra vonatkozó előrejelzéseiket és következtetéseiket foglalják össze „A Visegrádi Négyek SOFI mutatóiból levonható következtetések hazánk 2025-beli állapotára" című tanulmányukban. A szerzők a SOFI (State of the Future Index - Jövőállapot index) mutatóiból levonható következtetéseket osztják meg az olvasókkal. Egyúttal bemutatják a SOFI módszertanát, felépítését, meghatározzák a jövőre nézve figyelembe veendő fontosabb kihívásokat, az elemzéshez szükséges indikátorok körét és az indikátorértékeket is.

Kristóf Tamás egyetemi adjunktus a pénzügyi válságokra hívja fel figyelmünket „Várható pénzügyi csődök, pénzügyi válságok" címmel. Tanulmányában középtávra vonatkozó javaslatként említi meg, hogy fogalmazzunk meg egy pénzügyi válság-előrejelző rendszer kidolgozását és annak nemzetközi összefogásban történő üzemeltetését. Úgy véli, a pénzügyi válságok kialakulásának klasszikus útja 2050-ig világjelenségként megismétlődhet, s biztosak lehetünk abban, hogy ezek Magyarországot is elérik.

Lentner Csaba a Nemzeti Közszolgálati Egyetem professzora „A magyar gazdaság kilátásai 2025-re és 2050-re" címmel írja tanulmányát. A szerző felhívja a figyelmet arra, hogy egyre nehezebb a gazdaságipénzügyi környezet bizonytalanságai mellett a gazdasági tervezés, a váratlan események rendre felülírják az évtizedes költségvetési tervezési beidegződéseket, gyakorlatot. Emiatt az eddig elért pozitiv eredmények fenntartása is egyre nehezebb lesz.

Korompai Attila és Szabó Mátyás munkája „Új tendenciák településeink megújulásában" grafikonokkal is szemlélteti a megyékben lezajlott településszerkezeti és -strukturális, valamint gazdasági változásokat, illetve ezek irányait. A szerzők meglátása szerint a globális fejlődési trendek hazánkban is érvényesülni fognak, de a hazánkban jellemző negatív irányú változások (pl. a kistelepülések elnéptelenedése) továbbra is érvényesülni fognak.

Deák István „A globalizáció hatása a vidéki iparfejlődésre" címú munkájának összegzésében az ipartelepítés fontosságát emeli ki, amely biztosíthatná az egyes régiók sikerét. Ugyanakkor ezen ipari gazdálkodó egységeknek be kell épülniük, a régió, a helyi közösség szerves részévé kell válniuk, kapcsolatokat, jó együttmúködést kell kiépíteniük ahhoz, hogy valóban meghatározó tényezővé válhassanak. Véleménye szerint a globalizáció kiváló eszköz lehet az ipari fejlődési folyamatok elősegítésére, azonban ez önmagában nem lesz elég, szükség van megfelelő kormányzati együttmúködésre és intézkedésekre, valamint pozitív szemléletű, támogató társadalomra, amelynek tagjai akarnak és tudnak is összefogni és tenni a vidék fejlődéséért.

A tanulmánykötet 3. része a „Technikai-technológiai fejlődés és a környezet jövője" címet kapta.

Az első tanulmányt Meskó Bertalan orvosi jövőkutató jegyzi. „A technológiai fejlődés és az orvoslás jövője” címú írás előrevetíti, hogy köszönhetően a technikai fejlődésnek az orvosi szakma jelentős átalakuláson fog keresztülmenni. Az otthoni diagnosztikai eszközök térnyerése, a nanotechnológia fejlődése, a robotika, a gépesítés ezen a területen is egyre nagyobb tért hódít. Az orvosi tudás mennyiségének növekedésével emberi léptékben már nem lehet megküzdeni, és csak a technológia nyújthat segítséget. 
Monda Eszter „Az új infokommunikációs eszközök és közösségek várható elterjedése a felsőoktatásban" címmel szintén a technológia robbanásszerú fejlődéséből eredő változásokat emeli ki, s azt, hogy a technológia egyre inkább jelen lesz életünkben és átszövi azt.

Tóthné Szita Klára és Roncz Judit írása a környezetvédelem területére vezet. „Veszélyben a környezet! Megoldások keresése az energetika és a biotechnológia területén" címmel a hazai környezet állapotáról, a környezetet veszélyeztető tényezőkről alapos összegzést közölnek a szerzők. A globális problémák megjelenésével hazánkban is számolnunk kell, ezek felerősödése várható, ha nem változik a jelenlegi gyakorlat. Fontosnak tartják az innovatív technológiák alkalmazását a problémák megoldására.

Végezetül Tóth Attiláné „Alternatívák a 2050-es évekre, feladatok 2025-re" címmel dolgozatában mintegy globális összefoglalását adja a kötet valamennyi szerzője által üzent felhívásnak. Életünkben, környezetünkben minden mindennel összefügg. A minket érő katasztrófák (természeti, technikai, társadalmi) megjelenése kivédhetetlen, kölcsönhatásaik révén azok egyre erősebbek. Ezzel párhuzamosan a bennünket körülvevő informatikai-digitális fejlődés - bár életünkben nagyarányú fejlődést és kényelmet biztosít - újabb és még súlyosabb problémákat generál. Globálisan e két tényező hatását csakis az egyéni gazdasági érdekek háttérbe szorításával, vagyis komoly szemléletváltozással lehet semlegesíteni és kivédeni.
A kötet olvasásakor a mai magyar valóság széles spektrumát kapjuk, mely egyúttal a világban is zajló változások és felmerülő problémák képét tükrözik vissza. Izgalmas térképnek is nevezhetnénk korunk, napjaink valóságáról, a pozitív és negatív tendenciákról szóló írások összességét.

A szerzők megfogalmazzák félelmeiket hazánk és társadalmunk egészének jövőjét illetően. A tiszteletadáson túl, fontos hogy ismételten felhívják figyelmünket, elsősorban a döntéshozó helyzetben lévők figyelmét, azokra a mélyen elgondolkodtató, egyre nyomasztóbban ránk nehezedő problémákra, amelyek további életünket meghatározzák és befolyásolni fogják.

Összességében az olvasó azt a képet kapja, hogy a helyzet drámai, mind a hazai, mind a nemzetközi hatásokat figyelembe véve. Fiataljaink, akik a jövő döntéshozói lehetnének, nem látnak perspektívát magyar viszonyok között és nem szívesen vállalják fel a döntés felelősségét. Sajnos a vizsgálatok szerint, nem tudatosul bennük annak felelőssége sem, hogy jövőnk, jövőjük és a következő generációk jövője is, főként rajtuk múlik. Ugyanakkor a szerzők megfogalmaznak egyfajta reményt is, abban a tekintetben, hogy állami vezetőink, döntéshozóink a tudományos vizsgálatok, kutatások eredményeit figyelembe véve, ha kis lépésekben is, de jövőnkre is kiható tudatos, ésszerű tervezéssel, racionális döntésekkel, a körülmények körültekintő elemzésével, döntéseik hatásának alapos felmérésével megtalálhatják a lehetőségét a minket érő negatív társadalmi, gazdasági, technológiai, környezeti, hatások hatékonyabb kivédésére.

\section{HIVATKOZÁSOK}

\footnotetext{
${ }^{1}$ Schmidt P. A jövő kihívásai az egészségügyi ellátásban, különös tekintettel az egészségmegőrzés és egészségnevelés szempontjaira, valamint az egészségügy gazdasági-közgazdasági kérdéseire, In: Tóth Attiláné (szerk.), Tudomány, gazdaság, jövő: Gidai Erzsébet emlékére. 226 p., Budapest: Arisztotelész Stúdium Bt., 2011. pp. 174-181., (ISBN:978-963-877215-2)

${ }^{2}$ Schmidt P. Az egészségmegőrzés és egészségnevelés meghatározó feltételei és követelményei a jövő sikeres népegészségügyi programjának megvalósításában: Health Education and Health Promotion-Determinativa Conditions and Requirements for Realising the Public-Health Programme of the Future, GAZDASÁGI ÉLET ÉS TÁRSADALOM 2:(1) pp. 148-156. (2010)

${ }^{3}$ Schmidt P., Fehér J. Meghatározó feltételek és követelmények a jövő sikeres népegészségügyi programjának megvalósitásához, EGÉSZSÉGFEJLESZTÉS 51:(4) pp. 28-33. (2010)
} 
${ }^{4}$ Schmidt P., Fehér J. Új kihívások és feladatok az egészségvédelem és táplálkozás előtt, In: Nováky Erzsébet (szerk.), Magyarország 2025: Tanulmánykötet a Magyarország 2025 címú akadémiai kutatás alapján. 263 p., Budapest: Gazdasági és Szociális Tanács, 2010. pp. 183-198., 1. kötet. (ISBN:978 963884193 3)

${ }^{5}$ Schmidt P., Fehér J Feltételek a jövő sikeres népegészségügyi programjának megvalósításához, In: Tóthné Szita Klára, Gubik Andrea (szerk.), A jövőkutatás helye a 21. században. A jövőkutatás fejlődése és tudományterületi kapcsolatai: VII. Magyar (Jubileumi) Jövőkutatási Konferencia: 40 éves a magyar jövőkutatás. 225 p., Konferencia helye, ideje: Budapest, Magyarország, 2008.11.13-2008.11.14. Győr: Palatia Kiadó, 2009. pp. 106-117. (ISBN:978 963503393 5)

${ }^{6}$ Riez A., Schmidt P. Szociális szolgáltatások - globalizáció és egészségfejlesztés, EGÉSZSÉGFEJLESZTÉS 50:(3) pp. 27. (2009)

${ }^{7}$ Kiss É., Tóth A., S. Gubik A. (szerk.) Területi különbségek a hazai népesség egészségi állapotában és jövőbeni kilátások, Magyarország 2025-ben és kitekintés 2050-re, Budapest, Arisztotelész Kiadó, 2016. pp. 13-38., (ISBN:978-615-5394-034)

${ }^{8}$ Schmidt P. A népesség számának és egészségi állapotának várható alakulása, In: Tóth Attiláné, S. Gubik Andrea (szerk.), Magyarország 2025-ben és kitekintés 2050-re: . 299 p., Budapest: Arisztotelész Kiadó, 2016. pp. 39-52., (ISBN:978-6155394-03-4)

${ }^{9}$ Schmidt P., Simon T., Kappéter I. Lelki betegek és deviánsok helyzete és ellátása 2025-ben, In: Nováky Erzsébet (szerk.), Magyarország 2025: Tanulmánykötet a Magyarország 2025 címú akadémiai kutatás alapján. 263 p., Budapest: Gazdasági és Szociális Tanács, 2010. pp. 199-214., 1. kötet, (ISBN:978 96388419 3 3), 1. kötet 